\title{
Association between breastfeeding, obstetric factors and child development in northeast Brazil
}

Open acess

${ }^{1}$ Faculdade de Ciências da Saúde do Trairi - FACISA. Universidade Federal do Rio Grande do Norte - UFRN

${ }^{2}$ Universidade Federal do Rio Grande do Norte - UFRN

${ }^{3}$ Instituo Brasileiro de Geografia e Estatística. Natal, RN, Brasil

Corresponding author: andreaugusto@hotmail.com

Manuscript received: 18 April 2017 Manuscript accepted: 02 July 2017 Version of record online: 06 September 2017
André Augusto de Oliveira Severiano', Diego de Sousa Dantas, Vanessa Lopes Costa de Oliveira ${ }^{1}$, Johnnatas Mikael Lopes², Damião Ernane de Souza ${ }^{3}$, Adriana Gomes Magalhães ${ }^{1}$.

\section{Abstract}

Introduction: Child development is a complex process influenced by several factors, among others is highlighted the practice of breastfeeding. Beyond the biological effects, breastfeeding has effects on the social dimension and the psychological apparatus of the actors directly involved.

Objective: To analyse the influence of exclusive breastfeeding and associated factors on the neurodevelopment (ND) of children up to 36 months old.

Methods: A cross-sectional, community-based study with individuated data of 99 children up to 36 month sold, evaluated socio demographic, obstetric and neonatal variables and assessed ND through the Development Monitoring Instrument. The variables were analysed using descriptive statistics and regression testing. Data were considered significant when $p<0.05$.

Results: : Regarding ND, $70.71 \%$ of the children had achieved the motor milestones for their age, $98.99 \%$ of mothers breastfed, $37.38 \%$ of them had exclusive breastfed (EBF) for six months. Factors that positively influenced the ND were vaginal delivery when compared to children with other types of delivery, and EBF for 6 months when compared to children who had EBF less than six months.

Conclusion: The practice of exclusive breastfeeding for less than six months is associated with a higher prevalence of lower psychomotor development of children from zero to 36 months old. Other factors associated with delay in development are instrumented vaginal delivery with forceps or caesarean delivery.

Keywords: breastfeeding, child development, child health 


\section{INTRODUCTION}

In recent decades, studies show that the development of children is linked to advances in the health care of women and children, highlighting, among these, the prevention of disease in the period of early childhood, resulting in long-lasting effects that can affect growth and child development ${ }^{1}$.

In this regard, neurodevelopment (ND) has been highlighted. ND is considered a sequential process in which the human being acquires a vast amount of motor skills, progressing from spontaneous movements without functional purpose, to more organized and complex motor skills $^{2}$. Initially, it was believed that ND was characterized directly through the maturation of the central nervous system, today, however, it is known that ND is influenced by external stimuli. Therefore, the development of the child may be influenced by intrinsic and extrinsic factors ${ }^{1,2}$.

From this perspective, among the possible extrinsic factors contributing to better development, it is evident that breastfeeding (BF) is an essential practice for the child's health, preventing infant mortality. In addition, breastfeeding helps to promote the physical, mental and psychological health of the child, in reducing morbidity and mortality and improving ND in the medium and long term $^{3,4}$.

The World Health Organization recommends that the period of exclusive breastfeeding (EBF) should cover the first six months of the life of the child ${ }^{2}$. After this time supplementary nutrition should be initiated in conjunction with breastfeeding, preferably for up to two years of a child's life; this may be important for the physical and mental health of both ${ }^{5}$. The superiority of breast milk

\section{METHODS}

This is a cross-sectional community-based study of individuated data from a sample taken from PET (Programa de Educação pelo Trabalho/ Health Education Programme) Health Surveillance Project- An analysis of maternal and child health and health surveillance in Santa Cruz, Rio Grande do Norte, Brazil, whose main objective was to evaluate the health profile of women of childbearing age and children in that municipality. Originally, cluster sampling was used, using the Family Health Units (FHU) as a reference.

For this analysis, the records of 99 mothers of childbearing age (10-49 years) were used, whose children were between 0 and 36 months old, interviewed in the five FHU in the municipality by a team of student fellows of the PET Health Project- Surveillance. All survey participants were only included after signing the informed consent. The research protocol was approved by the Ethics Committee of the Federal University of Rio Grande do Norte under number 272/2011.

The dependent variable was the children's ND. In this study, the ND was evaluated based on the developmentmonitoring instrument (DMI) ${ }^{11}$. This instrument is used to perform the monitoring of children's ND up to 36 months old. The DMI evaluates motor milestones according to the child's age. The ND data were categorized into: children who had no delay in motor milestones; and children who had been outstanding in one or more motor milestones investigated. is due to its composition rich in essential nutrients and containing adequate amounts of nutrition for the child ${ }^{5,6}$.

Based on official data from the Second Breastfeeding Prevalence Research in the Brazilian capitals and Federal District, conducted in 2009 by the Ministry of Health, it was found that the prevalence of exclusive breastfeeding in children under six months was $41 \%$ among Brazilian capitals, with a mean duration of 1.8 months of practice ${ }^{3}$, less time than the 6 months recommended by $\mathrm{WHO}^{\mathrm{b}}$. The data was corroborated by Freitas et al., who verified breastfeeding less than six months and the association between a gestational age of less than 32 weeks and greater chances of breastfeeding interruption ${ }^{7}$.

The process of industrialization and urbanization in the mid-twentieth century, with modern industry introducing milk powder, has led to new cultural habits, which, through intense incentivizing campaigns, have conquered the market. This fact, combined with other factors such as the inclusion of women in the market, the lack of information about the benefits of breastfeeding, and fear about the aesthetics of the breast, have caused the lack of incentive to breastfeed ${ }^{8}$.

Although breastfeeding is a practice encouraged by institutional programmes and international organizations, the scientific evidence about the effects of exclusive breastfeeding on ND is scarce and studies contain methodological biases ${ }^{9,10}$. In this respect, the objective of this study is to analyse the influence of exclusive breastfeeding and associated factors on the ND of children up to 36 months old.

In addition to the ND, data were collected that, according to the Ministry of Health, are risk factors for the delay in child development and that are available in the child's personal health booklet ${ }^{4}$. Thus, the following independent variables were included: prenatal care received (yes or no); started in which trimester (1st, 2nd or 3rd); number of prenatal (PN) visits; place of delivery (hospital or elsewhere); type of pregnancy (single or multiple); type of delivery (vaginal not instrumented with forceps or caesarean section); child's gender; length; weight; Apgar score (dichotomized into two groups: less than 7 and greater than or equal to 7), classification according to gestational age (premature - birth at less than 37 gestational weeks; term - birth between 37 and 42 gestational weeks and post term-birth at 42 weeks or more); head circumference at birth; and age. If the child was breastfed, whether breastfeeding was exclusive (yes or no) and breastfeeding duration.

Other independent variables relate to the sociodemographic data of the mothers, which were collected through semi-structured interviews and later grouped as follows: age; skin colour (white, black, brown and others); marital status (single, widowed or divorced/separated and married or in a consensual union); practising a religion (yes or no); school type (public or private); education taken from the median for women of 10 years or less and 
in women with over 10 years of studies; home (owned, rented and other); income from paid work (no income, up to a minimum wage and higher than the minimum wage); number of rooms in the house; number of residents in the house; and number of children.

Data analysis was carried out calculating the proportions for categorical variables and mean and standard deviation for numerical variables, presented as

\section{RESULTS}

The maternal data revealed that the mean age was 26.14 years, ranging from 16 to 46 years. The majority of respondents called themselves mulatto $(70.71 \%)$, practised religion $(76.77 \%)$, and of these the majority were Catholic (84.21\%).

Regarding marital status, most were married or in a consensual union $(68.69 \%)$. Regarding education, it was observed that most had less than 10 years of formal education $(61.62 \%)$, and mostly attended public schools $(96.88 \%)$. parametric distribution. In order to analyse the relationship of maternal and neonatal variables and lactation with psychomotor development, Poisson regression was used, initially using the gross value of each variable, and then the variables were worked in the hierarchical model (adjusted value). Statistical analyses were performed in IBM SPSS ${ }^{\circledR}$ software, version 20.0. The significance level was 5\%.

Concerning housing, it was observed that the majority owned their own homes $(62.63 \%)$, with an average of 5.44 rooms, ranging from 2 to 16 , and 4.36 residents per household, ranging from 2 to 8 . In relation to income, most of the sample showed a monthly income lower than the minimum wage $(68.69 \%)$ with income ranging from 0 to $R \$ 2,500.00$ (Brazilian currency) and an average of R\$394.16. Regarding the number of children, the study found an average of around two children, ranging from 1 to 4 children (Table 1).

Table 1: Socio-demographic profile of the mothers interviewed. Santa Cruz, Rio Grande do Norte $(n=99)$

\begin{tabular}{|c|c|}
\hline Variables & Descriptive Analysis \\
\hline \multicolumn{2}{|l|}{ Marital status, n (\%) } \\
\hline Single & $26(26.26 \%)$ \\
\hline Divorced or widow & $5(5.05 \%)$ \\
\hline Married or in Consensual U & $68(68.69 \%)$ \\
\hline \multicolumn{2}{|l|}{ Race/skin colour, n (\%) } \\
\hline White & $20(20.20 \%)$ \\
\hline Mixed & $70(70.71 \%)$ \\
\hline Black & $9(9.09 \%)$ \\
\hline Others & $0(0 \%)$ \\
\hline \multicolumn{2}{|l|}{ Religious? n (\%) } \\
\hline Yes & $76(76.77 \%)$ \\
\hline No & $33(33.33 \%)$ \\
\hline \multicolumn{2}{|l|}{ Scholling, $n(\%)$} \\
\hline Less than 10 years of study & $38(38.38 \%)$ \\
\hline More than 10 years of study & $61(61.62 \%)$ \\
\hline \multicolumn{2}{|l|}{ School type } \\
\hline Public & $93(96.88 \%)$ \\
\hline Private & $3(3.12 \%)$ \\
\hline \multicolumn{2}{|l|}{ Home } \\
\hline Owned & $62(62.63 \%)$ \\
\hline Rented & $26(26.26 \%)$ \\
\hline Others & $11(11.11 \%)$ \\
\hline \multicolumn{2}{|l|}{ Health services quality } \\
\hline Very good/good & $44(44.45 \%)$ \\
\hline Reasonable & $29(29.29 \%)$ \\
\hline Very bad/bad & $26(26.26 \%)$ \\
\hline \multicolumn{2}{|l|}{ Monthly income, n (\%) } \\
\hline More than or equal to 545 reais & $31(31.31 \%)$ \\
\hline Less than 545 reais & $68(68.69 \%)$ \\
\hline Monthly income, media (SD) & $394.16(500.74)$ \\
\hline Mother age in years, media (SD) & $26.14(6.18)$ \\
\hline Number of rooms at home, media (SD) & $5.44(2.02)$ \\
\hline Number of residents, media (SD) & $4.36(1.31)$ \\
\hline Number of children, media (DP) & $1.91(0.89)$ \\
\hline
\end{tabular}


Regarding the profile of the children who were part of the sample of this study, they were found to have an average age of 14.57 months, ranging between 1 and 36 months, most were male $(51.52 \%)$, with $1 \mathrm{~min}$ and $5 \mathrm{~min}$ Apgar scores above 7 (68.69\% and 96.97\%, respectively), most were full term $(81.82 \%)$, and had an average birthweight of $3257.45 \mathrm{~g}$; head circumference of $34.85 \mathrm{~cm}$; and length $49.14 \mathrm{~cm}$ (Table 2).

Regarding ND, most of the children presented all motor milestones to chronological age at the time of evaluation (70.71\%). In pregnancy, almost all mothers received prenatal care $(98.99 \%)$, of these, $69.7 \%$ followed the recommendations of the Ministry of Health, and made 6 or more visits, mostly beginning in the first trimester of pregnancy $(77,65 \%)$, and carried a single foetus $(97.98 \%)$. Inherent to data on the mode of delivery the prevalence of vaginal delivery (64.65\%) was observed, all conducted in hospital. Regarding breastfeeding, only one child was not breastfed (1.01\%). $98.99 \%$ of breastfed infants had a mean time of 8.38 months of breastfeeding. This highlights that more than a third of the sample $(37.38 \%)$ practised EBF for 6 -months or more (Table 2).

Table 2: Obstetric and neonatal factors investigated in children aged 0-36 months. Santa Cruz, Rio Grande do Norte $(n=99)$

\begin{tabular}{|c|c|}
\hline Variables & Descriptive analys \\
\hline \multicolumn{2}{|l|}{ Children gender $\mathbf{n}(\%)$} \\
\hline Male & $51(51.52 \%)$ \\
\hline Female & $48(48.48 \%)$ \\
\hline \multicolumn{2}{|l|}{ Did pre-natal? n (\%) } \\
\hline Yes & 98 (98.99\%) \\
\hline No & $1(1.01 \%)$ \\
\hline \multicolumn{2}{|c|}{$\mathrm{N}^{\circ}$ of medical appointments during pre-natal $\mathrm{n}(\%)$} \\
\hline More than or equal to 6 & $69(69.7 \%)$ \\
\hline Less than 6 & $30(30.3 \%)$ \\
\hline \multicolumn{2}{|l|}{ Trimester in which the pre-natal started, $\mathrm{n}(\%)$} \\
\hline $1^{\circ}$ trimester & $76(77.55 \%)$ \\
\hline Others & $22(22.45 \%)$ \\
\hline \multicolumn{2}{|l|}{ Pregnancy n (\%) } \\
\hline Simple & $97(97.98 \%)$ \\
\hline Multiple & $2(2.02 \%)$ \\
\hline \multicolumn{2}{|l|}{ Where the birth was made, $\mathrm{n}(\%)$} \\
\hline Hospital & $99(100 \%)$ \\
\hline Others & $0(0 \%)$ \\
\hline \multicolumn{2}{|l|}{ Birth type, n (\%)" } \\
\hline Vaginal & $64(64.65 \%)$ \\
\hline Others & $35(35.35 \%)$ \\
\hline \multicolumn{2}{|l|}{ Apgar 1 min, $n(\%)$} \\
\hline More than or equal to 7 & $68(68.69 \%)$ \\
\hline Less than 7 & $31(31.31 \%)$ \\
\hline \multicolumn{2}{|l|}{ Apgar 5 min, $n(\%)$} \\
\hline More than or equal to 7 & $96(96.97 \%)$ \\
\hline Less than 7 & $3(3.03 \%)$ \\
\hline \multicolumn{2}{|l|}{ Gestational Age, n (\%) } \\
\hline Post term & $0(0 \%)$ \\
\hline Term & $81(81.82 \%)$ \\
\hline Pre term & $18(18.18 \%)$ \\
\hline \multicolumn{2}{|l|}{ Breastfeeding, $\mathrm{n}(\%)$} \\
\hline Breastfed & $98(98.99 \%)$ \\
\hline Did not breastfed & $1(1.01 \%)$ \\
\hline \multicolumn{2}{|l|}{ Is not breastfeeding yet $\mathrm{n}(\%)$} \\
\hline Yes & $37(37.37 \%)$ \\
\hline No & $62(62.63)$ \\
\hline \multicolumn{2}{|l|}{ Exclusive Breastfeeding, $n(\%)^{t}$} \\
\hline Did not made EBF & $2(2.02 \%)$ \\
\hline EBF during less than 6 months & $33(33.33 \%)$ \\
\hline EBF during 6 months & $37(37.38 \%)$ \\
\hline EBF during more than 6 months & $27(27.27 \%)$ \\
\hline
\end{tabular}


ND, $n(\%)$

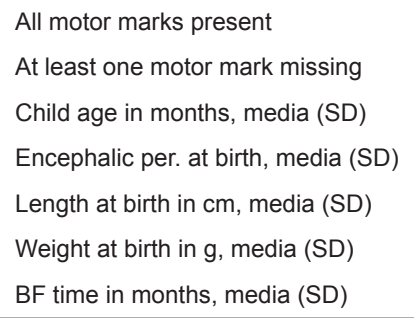

All motor marks present

At least one motor mark missing

Child age in months, media (SD)

Encephalic per. at birth, media (SD)

Length at birth in $\mathrm{cm}$, media (SD)

Weight at birth in g, media (SD)

BF time in months, media (SD)

\author{
$70(70.71 \%)$ \\ $29(29.29 \%)$ \\ 14.57(11.19) \\ $34.85(1.85)$ \\ $49.14(2.98)$ \\ $3257.45(584.18)$ \\ $8.38(7.08)$
}

Initially, by using the Poisson regression, each variable was compared individually with ND. At this point, significant differences were observed between the groups that received $\mathrm{EBF}$ for 6 months and those that received less than 6 months. Children who were exclusively breastfed for less than 6 months were 3.22 times more likely to have delayed ND, when compared to those who had 6 months of EBF. And children who had other types of delivery when compared to children who had vaginal delivery, were 2.5 times more likely to have delayed ND. The variables that showed little variance in the results (prenatal care and breastfeeding) and groups who represented only a small number of the sample (those who had EBF) were removed from the table (Table 3).

Table 3: Institutional factors of child victims of domestic accidents hospitalized at the Hospital de Urgência de Teresina, Piauí State, Brazil, 2016.

\begin{tabular}{|c|c|c|c|c|c|c|}
\hline \multirow[t]{2}{*}{ Variables } & \multirow[t]{2}{*}{ Gross PR } & \multicolumn{2}{|c|}{ Gross $95 \% \mathrm{Cl}$} & \multirow[t]{2}{*}{ Adjusted PR } & \multicolumn{2}{|c|}{ Adjusted $95 \% \mathrm{Cl}$} \\
\hline & & Lower & Upper & & Lower & Upper \\
\hline EBF during less than 6 months & 3.223 & 1.442 & 7.206 & 3.774 & 1.578 & 9.025 \\
\hline EBF during 6 months & 1 & . & . & 1 & . & . \\
\hline EBF during more than 6 months & 3.083 & 0.928 & 10.239 & 2.723 & 0.763 & 9.717 \\
\hline Less than 6 PN medical appointments & 1.150 & 0.591 & 2.238 & 1.103 & 0.531 & 2.292 \\
\hline More than 6 PN medical appointments & 1 & . & . & 1 & . & . \\
\hline Other birth types (forceps use or caesarean birth) & 2.5 & 1.103 & 5.664 & 0.486 & 0.206 & 1.147 \\
\hline Vaginal birth with no instruments & 1 & . & . & 1 & . & . \\
\hline Apgar $1 \mathrm{~min}$ less than 7 & 0.506 & 0.156 & 1.643 & 0.599 & 0.132 & 2.709 \\
\hline Apgar $1 \mathrm{~min}$ more or equal to 7 & 1 & . & . & 1 & . & . \\
\hline Apgar $5 \mathrm{~min}$ less than 7 & 0.842 & 0.116 & 6.133 & 1.114 & 0.072 & 17.310 \\
\hline Apgar 5 min more or equal to à 7 & 1 & . & . & 1 & . & . \\
\hline GA of less than 37 & 1.350 & .641 & 2.843 & 1.866 & 0.789 & 4.414 \\
\hline GA of more than 37 & 1 & . & . & 1 & . & . \\
\hline Schooling of less than 10 years & 1.246 & .640 & 2.425 & 0.756 & 0.343 & 1.668 \\
\hline Schooling of more than 10 years & 1 & . & . & 1 & . & . \\
\hline Monthly income of less than a minimum wage & 1.520 & .721 & 3.201 & 1.298 & 0.535 & 3.146 \\
\hline $\begin{array}{l}\text { Monthly income of more than or equal too ne mini- } \\
\text { mum wage }\end{array}$ & 1 & . & . & 1 & . & . \\
\hline
\end{tabular}

$\mathbf{P R}=$ Prevalence Ratio $\mathrm{Cl}=$ Confidence Interval

Subsequently, the Poisson regression was performed following the hierarchical model, with all the independent variables mentioned in the methodology. A significant difference was observe between the groups that received $\mathrm{EBF}$ for 6 months and those who received $\mathrm{EBF}$

\section{DISCUSSION}

Through the sample taken from the mother-child surveillance, comprised of 99 mothers and children from birth to 36 months of life, when analysing the influence of exclusive breastfeeding and associated factors on neurodevelopment, it was observed that most children investigated adequately presented all motor development milestones for their age, had been breastfed and a third of these were exclusively breastfed for six months. In addition, there was a negative association between instrumented vaginal delivery, caesarean delivery, EBF for less than 6 months and ND.

In this study, the evaluation through the development- for less time, with the children exclusively breastfed for less than 6 months presenting 3.77 times more likelihood to have delays in ND, when compared to those who had 6 EBF months. There were no significant differences among other variables.

monitoring tool showed that most of the children had normal ND for their age (70.71\%). Regarding prenatal conditions, most mothers received prenatal care $(98.99 \%)$, starting in the first trimester (77.55\%) and made 6 or more visits $(69.7 \%)$, as recommended by the Ministry of Health ${ }^{5}$ and can be justified by advances in the pre and neonatal care provided ${ }^{10}$, this result follows the expansion of prenatal care coverage. In Brazil, an increase has been recorded in the number of consultations per pregnant woman who uses the SUS (Sistema Único de Saúde/ Unified Health System), from 1.2 visits per birth in 1995 to 5.1 visits per delivery in 2003 . 
There was no significant influence on this research in the number of PN consultations on ND, however, this result does not corroborate the findings by Araújo et al. ${ }^{10}$ which evaluated premature infants hospitalized in neonatal units, and showed that a high number of pre-natal consultations was linked to delayed motor development of children. This result can be explained by the fact that most of the women who received more PN monitoring had more risk factors during pregnancy $^{10}$.

Years of schooling were recorded in the study, where most of the women had less than 10 years of formal education $(61.62 \%)$. This variable showed no significant difference when compared to ND. However, studies have shown that there is an association between the higher level of education of the mother, and a wider range of stimulation and interaction, and a better understanding of the development of her baby ${ }^{11}$. They also stressed that biological maturation, which is genetically determined, and learning processes, which are influenced by the environment and thus endowed with individual characteristics of the child's life, family (child caregivers) and the environment (home) form the central axis to determine the child's development; mothers with greater access to information about the children would have greater possibilities to interact positively with their children ${ }^{11-13}$.

Silva et $a l .{ }^{12}$, in a study of first-time mothers, assessed their knowledge of child development, and found that education and the mother's occupation are significantly correlated with their knowledge of parental care ${ }^{14}$. Relative to income, there was no relationship with ND, which contradicts other studies that negatively associated low income with the children's ND ${ }^{15-17}$.

Regarding gestational age (GA), no correlation was observed between it and ND. Although studies have demonstrated the existence of a link between prematurity and delayed development of the child ${ }^{14,15}$. From the data on GA, it was observed that most children were born at term $(81.82 \%)$, the data associated with the high number of mothers who received PN (98.99\%), shows that the absence of prenatal care may be linked to prematurity ${ }^{16,17}$.

Concerning the influence of mode of delivery on ND, the study results suggest that vaginal delivery is related to ND, compatible with neurological maturation and chronological age of the children, since children with other types of delivery had 2.5 times more likelihood to have delayed ND.

Analysing the BF characteristics, it was observed that $98.99 \%$ of women breastfed, and only $2.02 \%$ of the sample did $\mathrm{EBF}$, this can be explained by the success of the programme in encouraging BF c. Regarding period of BF, there was an average of 8.38 months, which is below the average observed in the Brazilian capital, which is 11.2 months $^{\mathrm{c}}$, it is noteworthy that some children were still receiving $\mathrm{BF}(37,37 \%)$. In this

\section{CONCLUSION}

It was observed that the practice of exclusive breastfeeding for less than 6 months is associated with a higher prevalence of delayed psychomotor development of children from birth to 36 months. In addition, instrumental vaginal delivery with forceps or caesarean section is also associated with an increased occurrence of delay in development. In order to assess with greater reliability the relationship between sense, Dee et al. ${ }^{18}$ show that BF brings many advantages for the child and the mother, among them we highlight better motor and language development.

Regarding the influence of EBF on ND, it was observed that children exclusively breastfed during 6 months have better ND than those breastfed for a shorter time. In recent years, several studies have shown an association between breastfeeding and development from childhood to adulthood $^{5,19}$. Some of them provide evidence that breast milk is the "gold standard" food for brain development $t^{8,18}$.

In a study of preterm infants, Vieira et al. ${ }^{20}$ showed that EBF for the first 6 months of life, compared with artificial milk, is much more efficient in promoting children's ND. This shows that the substituting EBF for artificial feeding possibly affect the child's ND.

Morley et $a .^{19}$, in a study of children born small for gestational age, noted that breastfeeding in addition to accelerating growth, leads to better neurodevelopment, which is significant for these children.

A systemic review of child and maternal health comparing EBF for 6 months versus 3-4 months found that EBF for 6 months showed greater efficacy in decreasing the childhood infection rate, but increased the potential risk of the development of anaemia having adverse results on neurodevelopmental ${ }^{21}$.

The prevalence of low-income women $(68.69 \%$ with income below the minimum wage) was observed in this sample. As breast milk produced by the mother is a more cost-effective food source, it is very important, especially in underdeveloped and developing countries that often have the problem of poverty and a high rate of mortality and morbidity infections, to use EBF as a weapon in reducing those infections, thus preventing future health problems, and is a food without expenses ${ }^{21,22}$.

Importantly, because this is a cross-sectional study, it cannot ensure the temporal precedence of the factors studied. Despite the observation of statistical significance that corroborates other evidence, the complexity of the healthdisease-care processes requires longitudinal or experimental studies where it is possible to investigate the possible risk factors for certain diseases. Moreover, the determination of ND through the unique analysis of motor milestones, following the hierarchical theory of development, although it is a classic form of assessment disregards individual and anticipatory responses to this pattern of development.

These limitations do not reduce the importance of the relevance of these results, which can contribute valuable information for the guidance and reorientation of public policies aimed at maternal and child health, especially with regard to the encouragement of exclusive breastfeeding as a factor for the promotion of development in children.

breastfeeding and psychomotor development, the importance of further studies is highlighted, with larger samples, longitudinal design and in different regions of the country to assess with greater reliability the relationship of the factors investigated. 


\section{REFERENCES}

1. Crestani AH, Mattana F, Moraes AB, Souza APR. Fatores socioeconômicos, obstétricos, demográficos e psicossociais como risco ao desenvolvimento infantil. Rev CEFAC. 2013; 15(4):847-56. DOI: http://dx.doi.org/10.1590/S1516-18462013000400013

2. Willrich A, Azevedo CCF, Fernandes JO. Desenvolvimento motor na infância: influência dos fatores de risco e programas de intervenção. Rev Neurocienc. 2008;17(1):51-6.

3. Sanches MTC, Buccini GS, Gimeno SGA, Rosa TEC, Bonamigo AW. Fatores associados à interrupção do aleitamento materno exclusivo de lactentes nascidos com baixo peso assistidos na atenção básica. Cad Saúde Pública. 2011;27(5):953-65. DOI: http://dx.doi.org/10.1590/S0102-311X2011000500013

4. Toma TS, Rea MF. Benefícios da amamentação para a saúde da mulher e da criança: um ensaio sobre as evidências: o papel dos serviços materno - infantil. Cad Saúde Pública. 2008; 24(Supl.2):S235-46. DOI: http://dx.doi.org/10.1590/S0102-311X2008001400009

5. Escarce AG, Araujo NG, Friche AAL, Mota AR. Influência da orientação sobre aleitamento materno no comportamento das usuárias de um hospital universitário. Rev CEFAC. 2013;15(6):1570-82. DOI: http://dx.doi.org/10.1590/S1516-18462013000600020

6. Melo CS, Gonçalves RM. Aleitamento Materno versus aleitamento artificial. Estudos. 2014;41(esp):7-14.

7. Freitas BAC, Lima LM, Carlos CFLV, Priore SE, Franceschini SCC. Duration of breastfeeding in preterm infants followed at a secondary referral service. Revi Paul Pediatr. 2016; 34(2):189-96. DOI: http://dx.doi.org/10.1016/j.rpped.2015.10.005

8. Antunes LS, Antunes LAA, Corvino MPF, Maia LC. Amamentação natural como fonte de prevenção em saúde. Ciênc Saúde Coletiva. 2008;13(1):103-9. DOI: http://dx.doi.org/10.1590/S1413-81232008000100015

9. Nobre EB, Issler H, Ramos JLA, Grisi SJFE. Aleitamento materno e desenvolvimento neuropsicomotor: uma revisão da literatura. Pediatria (São Paulo). 2010;32(3):204-10

10. Araújo ATC, Eickmann SH, Coutinho SB. Fatores associados ao atraso do desenvolvimento motor de crianças prematuras internadas em unidade de neonatologia. Rev Bras Saúde Matern Infant. 2013;13(2):119-28.

DOI: http://dx.doi.org/10.1590/S1519-38292013000200005

11. Escarce AG, Camargos TV, Souza VC, Mourão MP, Lemos SMA. Escolaridade materna e desenvolvimento da linguagem em crianças de 2 meses à 2 anos. Rev CEFAC. 2012; 14(6):1139-45. DOI: http://dx.doi.org/10.1590/S1516-18462011005000144

12. Silva AK, Vieira ML, Moura MLS, Ribas Jr RC. Conhecimento de mães primíparas sobre desenvolvimento infantil: um estudo em Itajaí, SC. Rev Bras Crescimento Desenvolv Hum. 2005;15(3):1-10. DOI: http://dx.doi.org/10.7322/jhgd.19766

13. Moura MSL, Ribas Jr RC, Piccinini CA, Bastos ACS, Magalhães CMC, Vieira $\mathrm{ML}$, et al. Conhecimento sobre desenvolvimento infantil em mães primíparas de diferentes centros urbanos do Brasil. Estudos Psicol. 2004;9(3):421-9. DOI: http://dx.doi.org/10.1590/S1413-294X2004000300004

14. Rodrigues OMPR, Bolsoni-Silva AT. Efeitos da prematuridade sobre o desenvolvimento de lactentes. Rev Bras Crescimento Desenvolv Hum. 2011;21(1):111-21. DOI: http://dx.doi.org/10.7322/jhgd.20000

15. Guimarães CLN, Reinaux CM, Botelho ACG, Lima GMS, Cabral Filho JE. Desenvolvimento motor avaliado pelo Test of Infant Motor Performance: comparação entre lactentes pré-termo e a termo. Rev Bras Fisioter. 2011;15(5):357-62. DOI: http://dx.doi.org/10.1590/S1413-35552011005000021

16. Almeida AC, Jesus ACP, Lima PFT, Araújo MFM, Araújo TM. Fatores de risco maternos para prematuridade em uma maternidade pública de Imperatriz-MA. Rev Gaúcha Enferm. 2012;33(2):86-94.

17. Halpern R, Barros AJD, Matijasevich A, Santos IS, Victora CG, Barros FC. Developmental status at age 12 months according to birth weight and family income: a comparison of two Brazilian birth cohorts. Cad Saúde Pública. 2008;24(3):S444-50. DOI: http://dx.doi.org/10.1590/S0102-311X2008001500010

18. Dee DL, Li R, Lee L, Grummer-Strawn LM. Associations Between Breastfeeding 
Practices and Young Children's Language and Motor Skill Development. Pediatrics. 2007; 119(92):592-8. DOI: http://dx.doi.org/10.1542/peds.2006-2089N

19. Morley R, Fewtrell MS, Abbott RA, Stephenson T, MacFadyen U, Lucas A.

Neurodevelopment in children born small for gestational age: a randomized trial of nutrientenriched versus standard formula and comparison with a reference breastfed group.

Pediatrics. 2004;11(3):515-21. DOI: http://dx.doi.org/10.1542/peds.113.3.515

20. Vieira GO, Almeida JAG, Silva LR, Cabral VA, Santana Netto PV. Fatores associados ao aleitamento materno e desmame em Feira de Santana, Bahia. Rev Bras Saude Mater Infant. 2004;4(2):143-50. DOI: http://dx.doi.org/10.1590/S1519-38292004000200004

21. Kramer MS, Kakuma R. The optimal duration of exclusive breastfeeding: a systematic review. Adv Exp Med Biol. 2004;554:63-77.

22. Fewtrell M, Wilson DC, Booth I, Lucas $A$. When to wean? How good is the evidence for six months' exclusive breastfeeding. BMJ. 2011;342(7790):209-212. DOI: http://dx.doi.org/10.1136/bmj.c5955

\section{Resumo}

Introdução: O desenvolvimento infantil é um processo complexo que sofre influência de diversos fatores, dentre os quais podemos destacar a prática do aleitamento materno. Isso porque, o aleitamento materno além dos efeitos biológicos, apresenta efeitos sobre a dimensão social e a aparelhagem psíquica dos atores diretamente envolvidos.

Objetivo: Analisar a influência do aleitamento materno exclusivo e de seus fatores associados sobre o DNPM de crianças até 36 meses de vida.

Método: Estudo transversal de base comunitária com dados individuados de 99 crianças até 36 meses de idade. Foram avaliadas variáveis sócio demográficas, obstétricas, neonatais e o DNPM através do Instrumento de Vigilância do Desenvolvimento. As variáveis foram analisadas por estatística descritiva e teste de regressão. Os dados foram considerados significativos quando $p<0,05$.

Resultados: Com relação ao DNPM, $70,71 \%$ das crianças apresentaram todos os marcos motores para a sua idade. $98,99 \%$ das mães amamentaram, dessas $37,38 \%$ realizaram aleitamento materno exclusivo (AME) por seis meses. Fatores que influenciaram positivamente no DNPM, foram: o parto vaginal, quando comparado com crianças que apresentaram outros tipos de parto, e o AME por 6 meses, quando comparado às crianças que o fizeram por menos de 6 meses.

Conclusão: A prática do aleitamento materno exclusivo por tempo inferior a 6 meses está associada a uma maior prevalência de atraso no desenvolvimento neuropsicomotor de crianças de zero a 36 meses de vida. Além disso, o parto vaginal instrumentalizado com fórceps ou parto cesáreo, também estão associados a uma maior ocorrência de atraso no desenvolvimento.

Palavras-chave: aleitamento materno, desenvolvimento infantil, saúde da criança

\footnotetext{
${ }^{-}$The authors (2017), this article is distributed under the terms of the Creative Commons Attribution 4.0 International License (http://creativecommons.org/licenses/by/4.0/), which permits unrestricted use, distribution, and reproduction in any medium, provided you give appropriate credit to the original author(s) and the source, provide a link to the Creative Commons license, and indicate if changes were made. The Creative Commons Public Domain Dedication waiver (http://creativecommons.org/publicdomain/ zero/1.0/) applies to the data made available in this article, unless otherwise stated.
} 